\title{
PENERAPAN PENDIDIKAN POLITIK BAGI PESERTA DIDIK (Suatu Penelitian Pada Siswa Kelas XI SMA Negeri 2 Indra Jaya Pidie)
}

\author{
Halik \\ Program Studi \\ Pendidikan Pancasila dan Kewarganegaraan \\ Fakultas Keguruan dan Ilmu Pendidikan \\ Universitas Jabal Ghafur Sigli
}

\begin{abstract}
ABSTRAK
Kata kunci: Pendidikan Politik, Peserta Didik.

Penelitian ini berjudul" penerapan pendidikan politik bagi peserta didik" (Suatu studi pada SMA Negeri 2 Indra Jaya) yang menjadi latar belakang dalam penelitian ini adalah Penerapan Pendidikan politik pada siswa kelas XI SMA Negeri 2 Indra Jaya masih rendah, hal tersebut diketahui dari hasil pengamatan awal peneliti, kurangnya pemahaman dan partisipasi peserta didik dalam bidang politik baik di lingkungan sekolah maupun dalam masyarakat tempat tinggalnya, karena peserta didik merupakan calon-calon pelaku politik pada masa yang akan datang, Jadi sudah seharusnya dari sejak dini, yaitu masa sekolah siswa mendapatkan penerapan pendidikan politik yang baik, Rumusan masalah penelitian ini bagaimana penerapan pendidikan politik bagi peserta didik? siapa saja yang berperan dalam penerapan pendidikan politik bagi peserta didik? dan apakah ada kendala dalam penerapan pendidikan politik bagi peserta didik? penelitian ini menggunakan metode deskriptif dengan pendekatan kualitatif. Penelitian ini bertujuan mendeskripsikan bagaimana dan siapa saja yang berperan dalam penerapan pendidikan politik bagi peserta didik, dan adakah kendala dalam penerapan pendidikan politik bagi peserta didik. Populasi dalam penelitian ini adalah seluruh siswa-siswi kelas X1 SMA Negeri 2 Indra Jaya. Sampel penelitian ini adalah kelas XI yaitu sebanyak 35 orang siswa, tehnik penarikan sampel menggunakan porpusive sampling. Instrumen yang digunakan dalam penelitian ini wawancara langsung dan angket. Hasil penelitian ini menunjukan bahwa penerapan pendidikan politik bagi peserta didik SMA Negeri 2 Indra Jaya dilakukan dengan cara penyampaian oleh guru melalui materi pelajaran, yang paling berperan dalam penerapan pendidikan politik untuk peserta didik adalah guru, siswa tidak menghadapi kendala dalam mempelajari pendidikan politik di sekolah. Penerapan pendidikan politik pada peserta didik dilakukan siswa pada saat pemilihan umum ketua OSIS, pendidikan politik diperoleh siswa melalui pelajaran yang diberikan oleh guru, penerapan pendidikan politik di sekolah siswa tidak menghadapi kendala, seperti pemilihan ketua osis. Diharapkan kepada semua pihak khususnya guru dapat memberikan pendidikan politik yang baik kepada peserta didik, peran guru akan sangat berpengaruh terhadap pendidikan politik bagi peserta didik di sekolah, Dinas pendidikan agar memberikan pelatihan yang bisa membekali seluruh guru untuk menyampaikan materi pendidikan politik yang baik dan benar.
\end{abstract}

\section{A. Latar belakang Masalah}

Pendidikan politik adalah proses pembelajaran dan pemahaman tentang hak, kewajiban, dan tanggung jawab setiap warga negara dalam kehidupan berbangsa dan bernegara (Bab I Pasal 1 ayat 4). Sehingga perlu ditumbuh kembangkan bagi setiap komponen bangsa terutama generasi muda.Generasi muda adalah jumlah yang menjanjikan untuk mendukung aktifitas politik negeri ini. Sehingga, kelompok usia sekolah setingkat SMA menjadi target untuk mendulang suara dari pemilih pemula dalam sebuah kegiatan politik seperti Pemilu. Sehingga sangatlah relevan dunia pendidikan bisa menjadi basis yang strategis untuk menaikkan pamor politik. Tak heran jika para caleg berupaya meraih simpati dari kalangan guru dan peserta didik, menurut pendapat Djamarah (2016:51) peserta didik adalah: setiap orang yang menerima pengaruh dari seseorang atau sekelompok orang yang menjalankan kegiatan pendidikan.

Sebagaimana yang telah kita ketahui larangan beraktifitas politik atau berkampanye di lembaga pendidikan sudah ada dari dulu. Hal ini sudah diatur dalam Undang-Undang Nomor 7 Tahun 2017 tentang pemilu. Namun dengan menghalalkan segala cara demi mencapai tujuan, para pelaku politik praktis ini tetap melakukan aktifitas politik di lingkungan sekolah meski dengan secara terselubung. Bagaimanpun 
bentuknya, baik secara terang-terangan maupun sembunyi-sembunyi, kampanye politik merupakan bentuk paparan yang telah mengarah pada politik praktis, Dengan paparan dan ancaman propaganda politik yang semakin besar ini generasi muda harus dibekali moral dan pengetahuan yang baik tentang politik. Selama menuntut ilmu dibangku pendidikan, para siswa tampaknya tak pernah mendapatkan pendidikan politik secara benar. Pembelajaran politik secara langsung di tengah-tengah kehidupan masyarakat melalui media yang sudah sarat dengan pembusukan dan anomali politik.

Dunia politik realitasnya akan selalu lekat dalam dimensi kehidupan manusia. Perwujudannya akan selalu bisa ditemui dalam skala yang besar hingga skala yang terkecil. Tentu dengan tingkat variasi kajian yang berbeda antara satu dimensi dengan dimensi lain. Robert Dahl dalam Syafie (2015:19) mengatakan: politik berasal dari kata "polis" yang berarti "Negara kota" dengan politik berarti ada hubungan khusus antara manusia yang hidup bersama, dalam hubungan itu timbul aturan, kewenangan dan akhirnya kekuasaan. Seperti yang dikatakan oleh para ilmuan politik dalam seminar LIPI (Lembaga ilmu pengetahuan Indonesia) bahwa"Sebagian dari kemerosotan politik di Indonesia disebabkan oleh kegagalan partaipartai atau kaum sipil umumnya untuk meransang proses kearah terwujudnya suatu sistem politik yang sehat sewaktu mereka mempunyai kesempatan untuk berbuat itu boleh dikatakan berada ditenga-tengah mereka."(Lipi 2015:156). Sejak dini generasi muda harus peduli dengan persoalan bangsa khususnya masalah politik. Mereka perlu belajar dan sekaligus memahami berbagai persoalan yang sedang dihadapi bangsa dan negerinya. Sehingga, pendidikan politik yang perlu diaplikasikan ke dalam lembaga pendidikan bukanlah dalam bentuk propaganda politik praktis yang akan mengarah pada proses pembusukan intelektual, melainkan pendidikan politik yang sesuai secara ilmiah dan bermoral. Penanaman nilai-nilai kearifan dan fatsun politik secara benar melalui dunia pendidikan harus dilakukan.

Sudah saatnya dunia pendidikan dilakukan secara keseluruhan dengan menempatkan berbagai persoalan yang langsung bersentuhan dengan hajat hidup rakyat banyak khususnya menyangkut permasalahan bangsa. Belajar politik bisa dimulai sejak berusia delapan tahun. Melalui pendidikan formal, mulai dari belajar melihat dan membentuk rukun tetangga, membangun kelurahan dan kecamatan, membentuk kota, mengembangkan provinsi, membangun negara, hingga merundingkan sistem antar negara di dunia, dapat mengisi ruang-ruang kualitas politik anak negeri. Jangan sampai dunia pendidikan bisa meraih segala ilmu yang ada tetapi dalam hal tertentu khususnya mengabaikan kehidupan sosial politik akan membuat ketidak pedulian anak-anak masa depan negeri ini dari berbagai persoalan nyata yang dihadapi bangsa dan negaranya. Kepedulian terhadap masalah bangsa adalah juga bentuk kepedulian terhadap sesama manusia, Para siswa harus mulai memahami persoalan-persoalan kebangsaan melalui proses pembelajaran yang dialogis dan interaktif. Karena demikian padatnya kurikulum yang ada maka pendidikan politik tidak perlu dijadikan sebagai materi pelajaran tersendiri. Nilai moral kearifan dan kesantunan politik perlu segera ditanamkan dan diaplikasikan ke dalam dunia pendidikan yang diberikan secara integratife ke dalam berbagai mata pelajaran tertentu seperti $\mathrm{PKn}$, sejarah dan sebagainya. Memupuk sikap menghargai pendapat orang lain dengan melakukan pemilihan ketua kelas atau diskusi dan debat yang baik tentang permasalahan bangsa adalah bentuk pendidikan politik praktis yang berharga.

Melalui pengajaran nilai santun dan bermoral politik semacam itu kepada generasi muda diharapkan kelak mereka mampu mencetak politikus masa depan yang cerdas dan bermoral. Sehingga hal itu akan dapat membantu meningkatkan kepedulian masyarakat terhadap permasalahan bangsa melalui politik parpol saat ini sangat buruk. Kualitas implementasi peran dan fungsi parpol seharusnya dimulai dari proses rekruitmen dan pencalonan pengurus parpol. Menurut pendapat Michael (2015:23) rekruitmen politik adalah: proses dengan mana individuindividu menjamin atau mendaftarkan diri untuk menduduki suatu jabatan. Proses rekruitmen dan pencalonan parpol harus dijalankan secara baik. Sehingga pengurus parpol bertanggung jawab menjalankan fungsi-fungsi parpol diantaranya fungsi pendidikan politik.Penerapan Pendidikan politik pada siswa kelas XI SMA Negeri 2 Indra Jaya Pidie masih rendah, hal tersebut diketahui dari hasil pengamatan awal peneliti dimana kurangnya pemahaman dan partisipasi siswa dalam bidang politik baik di lingkungan sekolah maupun dalam masyarakat tempat tinggalnya. Menurut Michael (2016:23) partisipasi politik 
adalah: keterlibatan individu sampai pada bermacam-macam tingkatan politik. Berdasarkan latar belakang di atas, maka penulis tertarik untuk mengadakan suatu penelitian dengan judul: "Penerapan Pendidikan Politik Bagi Peserta Didik Di SMA Negeri 2 Indra Jaya Pidie"

\section{B. Rumusan Masalah}

Sesuai dengan latar belakang masalah diatas maka yang menjadi fokus masalah dalampenelitian ini adalah:

1. Bagaimana penerapan pendidikan politik pada peserta didik di SMA Negeri 2 Indra Jaya Pidie?

2. Siapa saja yang berperan dalam memberikan pendidikan politik pada peserta didik di SMA Negeri 2 Indra Jaya Pidie?

3. Kendala apa saja yang dihadapi oleh peserta didik dalam penerapan pendidikan politik?

\section{Tujuan Penelitian}

Sesuai dengan rumusan masalah di atas, maka tujuan dari penelitian ini adalah untuk mengetahui tentang:

1. Untuk menegetahui penerapan pendidikan politik pada peserta didik di SMA Negeri 2 Indra Jaya Pidie.

2. Untuk mengetahui siapa saja yang berperan dalam memberikan pendidikan politik pada peserta didik di SMA Negeri 2 Indra Jaya Pidie.

3. Untuk mengetahui kendala yang dihadapi dalam penerapan pendidikan politik bagi peserta didik di SMA Negeri 2 Indra Jaya Pidie?

\section{Manfaat Penelitian}

a. Secara Teoritis

1. Hasil penelitian ini diharapkan dapat bermanfaat dan mampu memberikan masukan yang berguna bagi masyarakat sehingga dapat meningkatkan kesadaran dalam melakukan pilihan politik agar lebih baik.

2. Hasil penelitian ini dapat menjadi bahan pertimbangan bagi peneliti selanjutnya yang ingin meneliti masalah yang sama.

b. Secara Praktis

Hasil penelitian ini dapat di jadikan pedoman dalam melaksanakan kegiatan pendidikan atau pembelajaran politik pada guru dan peserta didik.

\section{E. Hasil penelitian}

Langkah awal yang penulis lakukan pada hari pertama adalah mengunjungi dinas pendidikan Kabupaten Pidie untuk memohon surat izin melakukan penelitian pada SMA Negeri 2 Indra Jaya Pidie, setelah mendapatkan surat izin penulis langsung mengumpulkan data, pertama yang dilakukan penulis adalah mengunjungi SMA Negeri 2 Indra Jaya, untuk menemui pihak bersangkutan pada sekolah tersebut untukmelakukan oservasi terlebih dahulu, pada hari selanjutnya peneliti langsung membagikan angket kepada siswa-siswi di SMA Negeri 2 Indra Jaya yang telah dipilih oleh penulis untuk dijadikan sampel dalam penelitian ini. Sejauh pengamatan peneliti para siswa dan siswi sangat antusias dalam mengisi angket yang dibagikan.Dari hasil penelitian yang peneliti lakukan diperoleh hasil sebagai berikut:

1) Bagaimana penerapan pendidikan politik pada peserta didik di SMA Negeri 2 Indra Jaya

Pertanyaan No .1. Apakah siswa tertarik dengan politik?

Dari keseluruhan siswa yang dijadikan sampelsebanyak 35 siswa, 22 orang siswa $(53,57 \%)$ menjawab tertarik dengan politik, dan 13 orang siswa $(46,43 \%)$ lainnya menjawab tidak tertarik dengan politik.Berdasarkan uraian tersebut maka dapat disimpulkan bahwa sebagian besar dari siswa SMA Negeri 2 Indra Jaya tertarik dengan politik, maka ini bisa mempengarui minat belajar siswa/siswi terhadap pendidikan politik, kerena mereka pada dasarnya banyak yang tertarik dengan politik. Pertanyaan No. 2 Apakah menurut siswa pendidikan politik perlu bagimereka?

Dari keseluruhan siswa yang dijadikan sampel yaitu sebanyak 35 siswa/siswi, sebanyak 31 orang siswa $(92,86 \%)$ menjawab pendidikan politik itu perlu, dan sisanya lagi sebanyak 4 orang siswa $(7,14 \%$ ) menjawab bahwa pendidikan politik itu tidak diperlukan.Berdasarkan uraian tersebut maka dapat disimpulkan bahwa pendidikan politik itu perlu bagi siswa. Dengan demikian sudah seharusnya pendidikan politik itu wajib untuk diberikan kepada siswa/siswi untuk pengetahuan mereka kedepan tentang perpolitikan.

Pertanyaan No. 3 Apakah siswa pernah mendapatkan pendidikan politik selama mereka belajar di sekolah SMA Negeri 2 Indra Jaya? 
Dari keseluruhan siswa yang di jadikan sampel yaitu sebanyak 35 siswa, maka sebanyak 26 orang siswa atau $(75 \%)$ menjawab pernah mendapatkan pendidikan politik selama mereka belajar disekolah SMA Negeri 2 Indra Jaya. Dan sebanyak 9 orang siswa lainnya atau (25\%) menjawab tidak pernah mendapatkan pendidikan politik selama mereka belajar di sekolah SMA Negeri 2 Indra Jaya.Berdasarkan uraian tersebut maka dapat disimpulkan bahwa siswa di sekolah SMA Negeri 2 Indra Jaya pernah mendapatkan pendidikan politik.

Pertanyaan No. 4 Bagaimanakah cara siswa mendapatkan pendidikan politik di sekolah SMA Negeri 2 Indra Jaya?

Dari keseluruhan siswa yang dijadikan sampel yaitu sebanyak 35 siswa, sebanyak 26 orang siswa $(78,67 \%)$ menjawab disampaikan oleh guru, dan 2 orang siswa $(3,57)$ menjawab sosialisasi langsung dari partai poliitik, sedangkan sisanya yaitu sebanyak 7 orang siswa $(17,86 \%)$ menjawab kedua-duanya benar.Berdasarkan uraian tersebut maka dapat disimpulkan bahwa siswa di sekolah SMA Negeri 2 Indra Jaya pada umumnya mendapatkan pendidikan politik dengan cara disampaikan oleh guru yang ada di sekolah mereka.

Pertanyaan No. 5 Apakah ada keluarga dari siswa yang terlibat langsung dalam partai politik?

Dari pertanyaan yang diajukan tersebut maka dari keseluruhan siswa yang dijadikan sampel yaitu sebanyak 35 siswa, sebanyak 7 orang siswa $(17,68 \%)$ menjawab bahwa ada anggota dari keluarga mereka yang terlibat langsung dalam partai politik, dan sebanyak 28 orang siswa $(82,14 \%)$ menjawab bahwa tidak ada dari anggota keluarga mereka yang terlibat langsung dalam partai politik.Berdasarkan uraian tersebut maka dapat disimpulkan bahwa sebagian besar dari angota keluarga siswa tidak ada yang terlibat dalam partai politik. Dengan tidak adanya anggota dari keluarga siswa yang terlibat langsung dalam partai politik maka kemungkinan besar siswa tidak pernah mendapatkan pengetahuan politik dari keluarganya.

Pertanyaan No. 6 Apakah siswa tertarik dengan pendidikan politik yang diajarkan di sekolah SMA Negeri 2 Indra Jaya?
Dari keseluruhan siswa yang di jadikan sampel yaitu sebanyak 35 siswa,sebanyak 15 orang siswa $(35,71 \%)$ menjawab tertarik dengan pendidikan politik yang diajarkan di sekolah mereka, dan sebanyak 20 orang siswa $(64,29 \%)$ menjawab tidak tertarik dengan pendidikan politik yang diajarkan di sekolah mereka.Berdasarkan uraian tersebut maka dapat disimpulkan bahwa sebagian besar siswa SMA Negeri 2 Indra Jaya tidak tertarik dengan pendidikan politik yang diajarkan di sekolah mereka. Hal ini bisa dipengarui oleh cara penerapan yang dilakukan oleh guru, sehingga membuat minat belajar mereka terhadap politik berkurang.

Pertanyaan No. 7. Apakah siswa mengerti dengan pendidikan politik yang diajarkan di sekolah SMA Negeri 2 Indra Jaya?

Dari keseluruhan siswa yang di jadikan sampel yaitu sebanyak 35 siswa, sebanyak 13 orang siswa $(32,14 \%)$ menjawab mengerti dengan pendidikan politik yang diajarkan di sekolah mereka, dan sebanyak 22 orang siswa $(67,68 \%)$ menjawab tidak mengerti dengan pendidikan politik yang diajarkan di sekolah mereka.Berdasarkan uraian tersebut maka dapat disimpulkan bahwa sebagian besar siswa SMA Negeri 2 Indra Jayakurang mengerti atau paham dengan pendidikan politik yang diajarkan di sekolah mereka.

Pertanyaan No. 8Apakah siswa mampu mengaplikasikan pengetahuan politik yang diajarkan di sekolah kedalam kehidupan pribadi mereka?

Dari keseluruhan siswa yang di jadikan sampel yaitu sebanyak 35 siswa, sebanyak 8 orang siswa $(17,86 \%)$ menjawab mampu mengaplikasikan pengetahuan politik yang diajarkan di sekolah kedalam kehidupan pribadi mereka, dansebanyak 21 orang siswa $(67,68 \%)$ menjawab kurang mampu mengaplikasikan pengetahuan politik yang diajarkan di sekolah kedalam kehidupan pribadi mereka, dan sisanya6 orang siswa(14,28\% ) menjawab tidak mampu mengaplikasikan pengetahuan politik yang diajarkan di sekolah kedalam kehidupan pribadi mereka.Berdasarkan uraian tersebut maka dapat disimpulkan bahwa sebagian besar siswa SMA Negeri 2 Indra Jaya dapat disimpulkan bahwa sebagian besar tidak mampu mengaplikasikan pengetahuan politik 
yang diajarkan di sekolah kedalam kehidupan pribadi mereka.

Pertanyaan No.9 Apakah siswa pernah berdiskusi dengan temannya mengenai pendidikan politik yang mereka dapatkan di sekolah?

Dari keseluruhan siswa yang dijadikan sampel yaitu sebanyak 35 siswa, sebanyak 12 orang siswa $(32,143 \%)$ menjawab pernah berdiskusi dengan temannya mengenai pendidikan politik yang mereka dapatkan di sekolah, dan sebanyak 18 orang siswa $(57,143 \%)$ menjawab kadang-kadang mereka berdiskusi dengan temannya mengenai pendidikan politik yang mereka dapatkan di sekolah, sedangkan sisanya sebanyak 5 orang siswa $(10,714 \%)$ menjawab tidak pernah berdiskusi dengan temannya mengenai pendidikan politik yang mereka dapatkan di sekolah. Berdasarkan uraian tersebut maka dapat disimpulkan bahwa sebagian besar siswa SMA Negeri 2 Indra Jaya pernah berdiskusi dengan temannya mengenai pendidikan politik yang mereka dapatkan di sekolah, walaupun hanya kadang-kadang saja atau tidak sering mereka lakukan. Maka dengan adanya diskusi dengan sesama teman tentang politik di luar jam pelajaran akan membuat siswa lebih paham lagi terhadap pendidikan politik yang sudah diajarkan oleh guru.

Pertanyaan No.10 Jenis politik seperti apa yang pernah siswa aplikasikan secara langsung?

Dari pertanyaan yang diajukan tersebut maka dari keseluruhan siswa yang di jadikan sampel yaitu sebanyak 35 siswa, sebanyak 13 orang siswa $(35,71 \%)$ menjawab jenis politik demonstrasi, dan sebanyak 22 orang siswa $(64,29 \%)$ menjawab tidak pernah sama sekali mengaplikasikan pendidikan politik secara lansung,seperti demontrasi,pemilu dan pilkada.Berdasarkan uraian tersebut maka dapat disimpulkan bahwa sebagian besar dari siswa SMA Negeri 2 Indra Jaya belum pernah mengaplikasikan secara langsug jenis politik apapun.

2) Siapa yang berperan dalam memberikan penerapan pendidikan politik pada peserta didik di SMA Negeri 2 Indra Jaya?

Pertanyaan No. 11. Siapakah yang paling berperan dalam memberikan pendidikan politik pada siswa?
Dari keseluruhan siswa yang dijadikan sampel yaitu sebanyak 35 siswa, sebanyak 11 orang siswa $(32,143 \%)$ menjawab yang paling berperan dalam memberikan pendidikan politik pada mereka adalah guru, dan sebanyak 4 orang swiswa $(7,143 \%)$ menjawab yang paling berperan dalam memberikan pendidikan politik pada mereka adalah orang tua, dan sebanyak 2 orang siswa $(3,57 \%)$ menjawab paling berperan dalam memberikan pendidikan politik pada mereka adalah teman sekolah, dan sebanyak 18 orang siswa $(57,143 \%)$ menjawab paling berperan dalam memberikan pendidikan politik pada mereka adalah semuanya yaitu, guru, teman,orang tua dan pihak dari luar. Berdasarkan uraian tersebut maka dapat disimpulkan bahwa yang paling berperan dalam memberikan pendidikan politik pada siswa adalah guru, ini dapat di lihat dari banyaknya murid yang memilih guru sebagai orang yang orang paling berperan dalam memberikan pendidikan politik pada mereka. Pertanyaan No. 12 Apakah siswa pernah ikut dalam kampanye politik yang ada didaerah mereka?

Dari pertanyaan yang diajukan tersebut maka dari keseluruhan siswa yang di jadikan sampel yaitu sebanyak 28 siswa, sebanyak 3 orang siswa $(10,71 \%)$ menjawab pernah ikut dalam kampanye politik yang ada didaerah mereka, dan sebanyak 25 orang siswa $(89,29 \%)$ menjawab tidak pernah ikut dalam kampanye politik yang ada didaerah mereka.Berdasarkan uraian tersebut maka dapat disimpulkan bahwa sebagian besar dari siswa SMA Negeri 2 Indra Jaya,tidak pernah ikut dalam kampanye politik yang ada didaerah mereka.

Pertanyaan No. 13 Pernahkah tokoh dari partai politik datang kesekolah mereka?

Dari pertanyaan yang diajukan tersebut maka dari keseluruhan siswa yang di jadikan sampel yaitu sebanyak 35 siswa, sebanyak 4 orang siswa $(7,14 \%)$ menjawab pernah tokoh dari partai politik datang kesekolah mereka, dan sebanyak 31 orang siswa $(92,86 \%)$ menjawab tidak pernah tokoh dari partai politik datang kesekolah mereka. Berdasarkan uraian tersebut maka dapat disimpulkan bahwa tidak pernah tokoh dari partai politik datang kesekolah mereka.Yaitu SMA Negeri 2 Indra Jaya. 
Pertanyaan No. 14 Apakah semua guru disekolah mereka semuanya berperan dalam memberikan pendidikan politik untuk mereka?

Dari pertanyaan yang diajukan tersebut maka dari keseluruhan siswa yang di jadikan sampel yaitu sebanyak 35 siswa, sebanyak 8 orang siswa $(21,43 \%)$ menjawab bahwa semua guru disekolah mereka semuanya berperan dalam memberikan pendidikan politik untuk mereka, dan sebanyak 27 orang siswa $(78,67 \%)$ menjawab tidak semua guru disekolah mereka semuanya berperan dalam memberikan pendidikan politik untuk mereka. Berdasarkan uraian tersebut maka dapat disimpulkan bahwatidak semua gurudisekolah SMA Negeri 2 Indra Jaya berperan dalam pendidikan politik yang mereka dapatkan.

Pertanyaan No. 15. Apakah teman sekolah mereka berperan dalam memberikan pendidikan politik yang mereka dapatkan disekolah?

Dari pertanyaan yang diajukan tersebut maka dari keseluruhan siswa yang di jadikan sampel yaitu sebanyak 35 siswa, sebanyak 18 orang siswa (50\%) menjawab bahwa teman sekolah mereka berperan dalam pendidikan politik yang mereka dapatkan disekolah, dan sebanyak 17 orang siswa (50\%) juga menjawab bahwa teman sekolah merekatidakberperan dalam memberikan pendidikan politik yang mereka dapatkan disekolah.Berdasarkan uraian tersebut makadapat disimpulkan bahwa teman sekolah merekaberperan dalam pendidikan politik yang mereka dapatkan disekolah.

Pertanyaan No. 16. Apakah mereka pernah mengamati atau mengikuti dialog politik di media massa seperti TV?

Dari pertanyaan yang diajukan tersebut maka dari keseluruhan siswa yang di jadikan sampel yaitu sebanyak 35 siswa, semuanya yaitu 35 orang siswa $(100 \%)$ menjawab pernah mengamati atau mengikuti dialog politik di media massa, seperti TV.Berdasarkan uraian tersebut maka dapat di simpulkan bahwa siswa SMA Negeri 2 Indra Jaya sebagian besar pernah mengamati atau mengikuti dialog politik di media massa, seperti TV.Ini dapat dilihat dari tidak adanya satu orang siswa punyang dijadikan sampel menjawab tidak pernah mengamati atau mengikuti dialog politik di media massa, seperti TV.

Pertanyaan No. 17. Apakah pernah organisasi politik memberikan sosialisasi langsung kepada siswa tentang politik?

Dari pertanyaan yang diajukan tersebut maka dari keseluruhan siswa yang di jadikan sampel yaitu sebanyak 35 siswa, sebanyak 9 orang siswa $(25 \%)$ menjawab bahwa pernah organisasi politik memberikan sosialisasi langsung kepada siswa tentang politik, dan sebanyak 26 orang siswa $(75 \%)$ menjawab bahwatidak pernahorganisasi politik memberikan sosialisasi langsung kepada siswa tentang politik.Berdasarkan uraian tersebut maka dapat disimpulkan bahwa tidak pernah organisasi politik datang kesekolah untuk memberikan sosialisasi langsung kepada siswa tentang politik. Ini dapat dilihat dari sedikitnya siswa yang menjawab bahwa pernah organisasi politik datang kesekolah untuk memberikansosialisasi langsung kepada mereka tentang politik.

Pertanyaan No. 18 Apakah pernah siswa mendapatkan pendidikan politik dari orang tua mereka?

Dari pertanyaan yang diajukan tersebut maka dari keseluruhan siswa yang di jadikan sampel yaitu sebanyak 35 siswa, sebanyak 23 orang siswa $(71,43 \%)$ menjawab bahwa pernah mendapatkan pendidikan politik dari orang tua mereka, dan sebanyak 12 orang siswa $(28,57 \%)$ menjawab bahwa tidak pernah mendapatkan pendidikan politik dari orang tua mereka.Berdasarkan uraian tersebut maka dapat disimpulkan bahwa sebagian besar dari siswa SMA Negeri 2 Indra Jaya pernah siswa mendapatkan pendidikan politik dari orang tua mereka. Ini dapat dilihat dari banyaknya siswa yang menjawabpernah mendapatkan pendidikan politik dari orang tua mereka perbandingan dengan siswa yang menjawabtidak pernah mendapatkan pendidikan politik dari orang tuanya.

Pertanyaan No. 19 Apakah ada peran dari lingkungan tempat siswa tinggal terhadap pendidikan politik yang mereka dapatkan?

Dari pertanyaan yang diajukan tersebut maka dari keseluruhan siswa yang di jadikan sampel yaitu sebanyak 35 siswa, sebanyak 15 orang siswa $(42,86 \%)$ menjawab bahwa ada peran dari lingkungan tempat siswa tinggal terhadap pendidikan politik yang mereka 
dapatkan, dan sebanyak 20 orang siswa $(57,14 \%)$ menjawab bahwa tidak ada peran dari lingkungan tempat siswa tinggal terhadap pendidikan politik yang mereka dapatkan.Berdasarkan uraian tersebut maka dapat disimpulkan bahwa lingkungan tempat tinggal mereka mempunyai peran dalam pendidikan politik yang mereka dapatkan walaupun tidak banyak peran dari lingkungan tempat mereka tinggal dalam pendidikan politik yang mereka dapatkan.Ini dapat dilihat dari sedikitnya perbedaan antara siswa yang menjawab tidak ada peran dari lingkungan tempat siswa tinggal terhadap pendidikan politik yang mereka dapatkan, dibandingkan dengan adanya peran dari lingkungan tempat siswa tinggal terhadap pendidikan politik yang mereka dapatkan.

Pertanyaan No. 20 Pernahkah siswa ikut dalam seminar pendidikan politik?

Dari pertanyaan yang diajukan tersebut maka dari keseluruhan siswa yang di jadikan sampel yaitu sebanyak 35 siswa, sebanyak 7 orang siswa $(17,86 \%)$ menjawab bahwa pernah ikut dalam seminar pendidikan politik, dan sebanyak 28 orang siswa $(82,14 \%)$ menjawab bahwa tidak pernah ikut dalam seminar pendidikan politik. Berdasarkan uraian tersebut maka dapat disimpulkan bahwa sebagian besar dari siswa SMA Negeri 2 Indra Jaya tidak pernah ikut dalam seminar pendidikan politik.Ini dapat dilihat dari banyaknya siswa yang menjawab tidak pernah ikut dalam seminar pendidikan politik perbandingan antara siswa yang menjawab pernah ikut dalam seminar pendidikan politik.

3) Kendala-kendala apa yang dihadapi dalam penerapan pendidikan politik pada peserta didik di SMA Negeri 2 Indra Jaya?

Pertanyaan No. 21. Apakah siswa senang dengan cara guru menerapkan pendidikan politik kepada mereka?

Dari pertanyaan yang diajukan tersebut maka dari keseluruhan siswa yang di jadikan sampel yaitu sebanyak 38 siswa, sebanyak 25 orang siswa $(78,67 \%)$ menjawab bahwa mereka senang dengan cara guru menerapakan pendidikan politik, dan sebanyak 10 orang siswa $(21,43 \%)$ lainnya menjawab bahwa mereka tidak senang dengan cara guru mereka menerapakan pendidikan politik.
Berdasarkan uraian tersebut maka dapat disimpulkan bahwa pada umumnya dari siswa SMA Negeri 2 Indra Jaya senang dengan cara guru mereka dalam menerapakan pendidikan politik kepada mereka. Ini dapat dilihat dari banyaknya siswa yang menjawab senang dengan cara gurumereka menerapkanpendidikan politik kepada mereka, dibandingkan dengan siswa yang menjawab bahwa mereka tidak senang dengan cara guru mereka menerapakan pendidikan politik.

Pertanyaan No. 22. Apakah siswa di beri kebebasan untuk berapresiasi terhadap politik, sebagai wujud pendidikan politik di sekolahnya?

Dari pertanyaan yang diajukan tersebut maka dari keseluruhan siswa yang di jadikan sampel yaitu sebanyak 35 siswa, sebanyak 29 orang siswa $(89,29 \%)$ menjawab bahwa mereka di beri kebebasan untuk berapresiasi terhadap politik sebagai wujud pendidikan politik di sekolahnya,dan sisanya sebanyak 6 orang siswa $(10,71 \%)$ menjawab bahwa tidak di beri kebebasan untuk berapresiasi terhadap politik sebagai wujud pendidikan politik yang didapatkan di sekolahnya.Berdasarkan uraian tersebut maka dapat disimpulkan bahwa pada umumnya dari siswa SMA Negeri 2 Indra Jaya diberi kebebasan untuk berapresiasi terhadap politik sebagai wujud pendidikan politik yang didapatkan di sekolahnya. Ini dapat dilihat dari tingginya perbedaan antara siswa yang menjawab bahwa mereka di beri kebebasan untuk berapresiasi terhadap politik sebagai wujud pendidikan politik yang didapatkan di sekolahnya, dibandingkandengansiswa yang menjawab bahwa mereka tidak di beri kebebasan untuk berapresiasi terhadap politik sebagai wujud pendidikan politik yang didapatkan di sekolahnya.

Pertanyaan No. 23. Apakah ada kendala yang dihadapi oleh siswa dalam penerapan pendidikan politik seperti,pemilihan ketua kelas atau pemilihan ketua osis di sekolahnya?

Dari pertanyaan yang diajukan tersebut maka dari keseluruhan siswa yang dijadikan sampel yaitu sebanyak 35 siswa, sebanyak 12 orang siswa $(32,14 \%)$ menjawab bahwa mereka menghadapi kendala dalam penerapan pendidikan politik seperti,pemilihan ketua kelas atau pemilihan 
ketua osis di sekolahnya,dan swisanya sebanyak 23 orang siswa $(67,86 \%)$ lainnya menjawab bahwa mereka tidak menghadapi kendala dalam penerapan pendidikan politik seperti,pemilihan ketua kelas atau pemilihan ketua OSIS di sekolahnya.Berdasarkan uraian tersebut maka dapat disimpulkan bahwa pada umumnya dari siswa SMA Negeri 2 Indra Jaya tidak menghadapi kendala dalam penerapan pendidikan politik seperti, pemilihan ketua kelas atau pemilihan ketua osis di sekolahnya.

Pertanyaan No. 24 Apakah siswa selalu ikut dalam kegiatan yang bernuansa politik yang ada di sekolah mereka?

Dari pertanyaan yang diajukan tersebut maka dari keseluruhan siswa yang dijadikan sampel yaitu sebanyak 35 siswa, sebanyak 8 orang siswa $(21,43 \%)$ menjawab bahwa mereka selalu ikut dalam kegiatan yang bernuansa politik yang ada di sekolah mereka selalu ikut dalam kegiatan yang bernuansa politik yang ada di sekolah mereka, dan sebanyak 27 orang siswa $(78,67 \%)$ lainnyamenjawab bahwa mereka tidak selalu ikut dalam kegiatan yang bernuansa politik yang ada di sekolah mereka. Berdasarkan uraian tersebut maka dapat disimpulkan bahwa pada umumnya dari siswa SMA Negeri 2 Indra Jaya tidak selalu mengikuti semua kegiatan yang bernuansa politik yang ada disekolah mereka. Ini dapat dilihat dari lebih banyaknya siswa yang menjawab bahwa mereka tidak selalu mengikuti semua kegiatan yang bernuansa politik yang ada disekolah mereka, dibandingkan dengan siswa yang menjawab bahwa mereka selalu ikut dalam kegiatan yang bernuansa politik yang ada di sekolah mereka.

Pertanyaan No. 25 Apakah ada pihak yang melarang siswa ketika siswa berbicara masalah politik?

Dari pertanyaan yang diajukan tersebut maka dari keseluruhan siswa yang di jadikan sampel yaitu sebanyak 35 siswa, sebanyak 6 orang siswa $(14,29 \%)$ menjawab bahwa ada pihak yang melarang siswa ketika siswa berbicara masalah politik,dan sebanyak 29 orang siswa $(85,71 \%)$ lainnya menjawab bahwa tidak ada pihak yang melarang siswa ketika siswa berbicara masalah politik.Berdasarkan uraian tersebut maka dapat disimpulkan bahwa pada umumnya tidak ada pihak yang melarang siswa dari
SMA Negeri 2 Indra Jaya berbicara masalah politik disekolahnya.Ini dapat dilihat dari tingginya perbedaan antara siswa yang menjawab ada pihak yang melarang siswa,ketika siswa berbicara masalah politik, dibandingkan dengan siswa yang menjawab tidak ada pihak yang melarang siswa,ketika siswa berbicara masalah politik.

Pertanyaan No. 26. Apakah orang tua siswa melarang siswa ketika siswa mengelaurkan pendapat siswa dalam bidang politik ?

Dari pertanyaan yang diajukan tersebut maka dari keseluruhan siswa yang di jadikan sampel yaitu sebanyak 35 siswa, sebanyak 4 orang siswa $(7,14 \%)$ menjawab bahwa orang tua siswa melarang siswa ketika siswa mengelaurkan pendapat siswa dalam bidang politik, dan sebanyak 31 orang siswa $(92,86 \%)$ lainnya menjawab bahwa orang tua tidak siswa melarang siswa ketika siswa mengeluarkan pendapat siswa dalam bidang politik.Berdasarkan uraian tersebut maka dapat disimpulkan bahwa pada umumnya orang tua dari siswa SMA Negeri 2 Indra Jaya tidak pernah melarang mereka ketika mereka mengeluarkan pendapat siswa dalam bidang politik. Ini dapat dilihat dari banyaknya siswa yang menjawab bahwa orang tua mereka tidak melarang mereka ketika mereka mengeluarkan pendapat dalam bidang politik dibandingkan dengan siswa yang menjawab bahwa orang tua mereka melarang ketika mereka mengeluarkan pendapat dalam bidang politik.

Pertanyaan No. 27 Apakah siswa mempunyai kesulitan untuk memahami tentang politik?

Dari pertanyaan yang diajukan tersebut maka dari keseluruhan siswa yang di jadikan sampel yaitu sebanyak 35 siswa, sebanyak 7 orang siswa $(17,86 \%)$ menjawab bahwa mereka mempunyai kesulitan untuk memahami tentang politik, dan sebanyak 26 orang siswa $(78,67 \%)$ menjawab bahwa mereka hanya kadang-kadang saja atau sesekali mempunyai kesulitan untuk memahami tentang politik, dan sisanya 2 orang siswa $(3,57 \%)$ menjawab tidak mempunyai kesulitan untuk memahami tentang politik. Berdasarkan uraian tersebut maka dapat disimpulkan bahwa pada umumnya siswa SMA Negeri 2 Indra Jaya tidak terlalu sering atua hanya kadang- 
kadang saja mempunyai kesulitan untuk memahami tentang politik. Ini dapat dilihat dari lebih banyaknya siswa yang menjawab bahwa mereka hanya tidak sering mempunyai atau menghadapi kesulitan untuk memahami tentang politik.

Pertanyaan No. 28 Apakah siswa selalu menanyakan kepada guru ketika menghadapi kesulitan pada saat mempelajari politik?

Dari pertanyaan yang diajukan tersebut maka dari keseluruhan siswa yang di jadikan sampel yaitu sebanyak 35 siswa, sebanyak 8 orang siswa $(28,57)$ menjawab bahwa mereka selalu menanyakan kepada guru ketika menghadapi kesulitan pada saat mempelajari politik, dan sebanyak 19 orang siswa $(53,57 \%)$ menjawab bahwa hanya kadangkadang saja atau sesekali mereka menanyakan kepada guru ketika menghadapi kesulitan pada saat mempelajari politik, dan sisanya 8 orang siswa lagi $(17,86 \%)$ menjawab tidak pernah menanyakan kepada guru ketika menghadapi kesulitan pada saat mempelajari politik.Berdasarkan uraian tersebut maka dapat disimpulkan bahwa pada umumnya siswa SMA Negeri 2 Indra Jaya tidak terlalu sering atau hanya kadangkadang saja menanyakan kepada guru ketika menghadapi kesulitan pada saat mempelajari politik.Ini dapat dilihat dari lebih banyaknya siswa yang menjawab bahwa mereka hanya kadang-kadang menanyakan kepada guru ketika menghadapi kesulitan pada saat mempelajari politik.

Pertanyaan No. 29 Apakah pada saat siswa membahas masalah politik disekolah ada pihak yang merasa terganggu dengan sikap siswa?

Dari pertanyaan yang diajukan tersebut maka dari keseluruhan siswa yang di jadikan sampel yaitu sebanyak 35 siswa, sebanyak 6 orang siswa $(14,29 \%)$ menjawab bahwa ada pihak yang merasa terganggu pada saat siswa membahas masalah politik di sekolah, dan sebanyak 29 orang siswa $(85,71 \%)$ menjawab tidak ada pihak yang merasa terganggu pada saat siswa membahas masalah politik di sekolah. Berdasarkan uraian tersebut maka dapat disimpulkan bahwa pada umumnya dari siswa SMA Negeri 2 Indra Jaya tidak ada pihak yang merasa terganggu pada saat siswa membahas masalah politik di sekolah.Ini dapat dilihat dari lebih banyaknya siswa yang menjawab bahwa tidak ada pihak yang merasa terganggu pada saat siswa membahas masalah politik di sekolah, dibandingkan dengan siswa yang menjawab bahwa ada pihak yang merasa terganggu pada saat siswa membahas masalah politik di sekolah.

Pertanyaan No.30 Apakah yang akan di lakukan siswa saat mendapatkan kendala dalam memahami pendidikan politik?

Dari pertanyaan yang diajukan tersebut maka dari keseluruhan siswa yang di jadikan sampel yaitu sebanyak 35 siswa, sebanyak 30 orang siswa $(96,43 \%)$ menjawab bahwa mereka akan mencari solusi terhadap kendala yang mereka hadapi atas atas kendala yang mereka hadapi dalam memahami pendidikan politik, dan sisanya 5 orang siswa $(3,57 \%)$ menjawab tidak peduli atau tidak mau mencari solusi terhadap kendala yang siswa hadapi dalam memahami pendidikan politik.Berdasarkan uraian tersebut maka dapat disimpulkan bahwa pada umumnya siswa dari SMA Negeri 2 Indra Jaya akan mencari solusi atas kendala yang mereka hadapi dalam memahami pendidikan politik. Ini dapat di lihat dari banyaknya siswa yang menjawab akan mencari solusi terhadap kendala yang mereka hadapi dalam memahami pendidikan politik, sangat berbanding jauh dengan siswa yang menjawab tidak peduli atau tidak mau mencari solusi terhadap kendala yang siswa hadapi dalam memahami pendidikan politik.

\section{F. Pembahasan}

Berdasarkan data yang sudah terkumpul dan sudah dianalisis maka penulis dapat menyimpulkan peserta didik di SMA Negeri 2 Indra Jaya tertarik dengan politik. Menurut Sinolungan (2016:42) Peserta didikdalam arti luas adalah setiap orang yang terkait dengan proses pendidikan sepanjang hayat, sedangkan dalam arti sempit adalah setiap siswa yang belajar di sekolah. Adapun pengertian dari politik itu sendiri menurut Robert Dahl dalam Syafie (2014:19): politik berasal dari kata "polis" yang berarti "Negara kota" dengan politik berarti ada hubungan khusus antara manusia yang hidup bersama, dalam hubungan itu timbul aturan, kewenangan dan akhirnya kekuasaan. peserta didik di SMA Negeri 2 Indra Jaya pernah mendapatkan pendidikan politik selama mereka belajar di sekolah mereka SMA Negeri 2 Indra Jaya, siswa memperoleh pendidikan politik di 
sekolah dengan cara di sampaikan oleh guru melalui meteri pelajaran. Said Rekshohadi Projo (2015:18) mengatakan:"pendidikan adalah suatu usaha untuk mempengaruhi manusia, agar ia bersedia dan mampu mewujudkan apa yang ia pandang makna eksitensi manusia di dunia ini. Dan Politik berarti berbagai macam kegiatan yang terjadi didalam suatu Negara yang berkaitan dengan proses menetapkan tujuan dan bagaimana mencapai tujuan itu. Philipus dkk: (2014:105) Adapun pengertian pendidikan politik adalah proses pembelajaran dan pemahaman tentang hak, kewajiban, dan tanggung jawab setiap warga negara dalam kehidupan berbangsa dan bernegara. Pendidikan juga telah lama dipandang sebagai suatu variabel penting dalam kegiatan menjelaskan tingkah laku politik, dan terdapat banyak pembuktian secara tidak langsung bahwa pendidikan itu penting sebagai agen sosialisasi politik (Michael:2015:67).

Yang peneliti simpulkan bahwa sebagian besar dari siswa menyatakan senang dengan cara guru mereka dalam menerapkan pendidikan politik kepada mereka. walaupun terkadang agak sulit untuk di pahami, akan tetapi hal itu tidak menjadi masalah besar bagi siswa kerena pada saat ada kendala dalam memahami pendidikan politik, siswa selalu berusaha mencari solusi baik berdiskusi dengan teman sekolah atau menanyakan langsung kepada guru. Peserta didik mendapatkan pendidikan politik di sekolah hanya dari guru saja, maka dapat di simpulkan bahwa sekolah khususnya guru memegang peran yang sangat penting terhadap pendidikan politik siswa, seperti yang di kemukakan oleh Maran (2015:136) sekolah juga bisa mempengaruhi kepekaan anak-anak akan pentingnya politik, dan kepercayaan mereka bahwa mereka dapat berpartisipasi dalam politik dan bahwa partisipasi mereka itu dapat membuat satu perbedaan.

Menurut siswa tidak ada pihak manapun yang pernah datang kesekolah mereka untuk memberikan sosialisisali langsung kepada peserta didik tentang pendidikan politik. Menurut Maran (2015:136) sosiologi politik merupakan suatu proses bagaimana memperkenalkan sistem politik pada seseorang, dan bagaimana orang tersebut menentukan tanggapan serta reaksi-reaksinya terhadap gejala-gejala politik. Termasuk partai politik juga tidak pernah datang ke sekolah untuk memberikan sosialisasi tentang pendidikan politik. Menurut Carl J.Fiederich (Miriam Budiarjo:2014:161) partai politik adalah: suatu kelompok manusia yang diorganisasikan secara stabil dengan tujuan mengamankan atau memelihara pengusaan para pemimpinnya atas suatu pemerintahan, dengan demikian dapat memberikan anggota-anggotanya keuntungankeuntungan serta kelebihan-kelebihan ideal dan material.

\section{G. PENUTUP}

Siswa di SMA Negeri 2 Indra Jaya juga tidak pernah berpartisipasi atau terlibat langsung dalam kegiatan apapun yang bernuansa politik yang ada di luar sekolah. Menurut Michael (2014:23) partisipasi politik adalah: keterlibatan individu sampai pada bermacam-macam tingkatan politik. Sebagian besar dari siswa juga menyatakan pihak yang paling berperan dalam pendidikan politik yang mereka dapatkan adalah guru. walaupun orang tua, teman sekolah, dan lingkungan tempat siswa tinggal juga berperan dalam pendidikan politik yang mereka dapatkan, akan tetapi gurulah yang memegang peran paling penting terhadap pendidikan politik yang siswa peroleh. Penulis juga menyimpulkan bahwa media massa seperti TV juga dapat berperan dalam pendidikan politik yang di dapatkan oleh siswa. Karena pada umumnya siswa sering memperhatikan atau mengikuti dialog-dialog tentang politik yang ada di media massa seperti TV dan hal ini sangat berpengaruh terhadap pendidikan politik yangdi dapatkan siswa. Seperti yang dikemukakan oleh Michael dan Althoff (2016:168) semakin peka atau terbuka seseorang terhadap perangsang politik lewat kontak pribadi dan organisatoris dan lewat media massa, maka semakin besar kemungkinanya dia turut serta dalam kegiatan politik.

Menurut hasil penelitian juga di ketauhi bahwa siswa SMA Negeri 2 Indra Jaya tidak sering menghadapi kendala atau kesulitan pada saat siswa mempelajari politik maupun dalam mengaplikasikan pendidikan politik di sekolah seperti pemilihan ketua osis, walaupun terkadang ada kendala yang mereka hadapi maka siswa selalu mencoba mencari solusi terhadap masalah yang siswa hadapi tersebut, seperti berdiskusi dengan sesema teman sekolah atau bertanya kepada guru.

\section{G.1 Kesimpulan}

Berdasarkan hasil penelitian dan pembahasan yang telah peneliti jelaskan, maka peneliti akan mangemukakan beberapa kesimpulan antara lain: 
1. Penerapan Pendidikan politik di sekolah dilakukan peserta didik pada saat melakukan pemilihan OSIS dan pemilihan ketua kelas, siswa juga mempelajari politik dari pelajaran yang diberikan oleh guru.

2. Penerapan pendidikan politik didapatkan peserta didik melalui pelajaran yang diberikan oleh guru, orang tua dan masyarakat yang ada disekitar tempat tinggal siswa, namun yang paling dominan dan secara langsung memberikan pendidikan politik adalah guru disekolah.

3. Penerapan pendidikan politik yang dilakukan siswa di sekolah tidak pernah menghadapi kendal pada saat mempelajari pendidikan politik, jika menghadapi kendala siswa selalu berusaha mencari solusi, baik itu bertanya kepada guru, atau berdiskusi dengan sesama teman sekolah untuk memecahkan masalah tersebut dan juga tidak pernah menghadapi kendala pada saat menerapkannya di sekolah, seperti pemilihan ketua OSIS.

\section{G.2 Saran-Saran}

1. Kepada pihak sekolah diharapkan supaya lebih berperan dalam menerapkan pendidikan politik bagi peserta didik, kerena dengan adanya kepedulian pihak sekolah terhadap penerapan pendidikan politik bagi peserta didik akan membantu peserta didik dalam memperoleh pendidikan politik yang baik dan benar. karena jika pendidikan politik yang di dapat baik dan benar maka juga akan melahirkan perilaku politik yang baik pula.

2. Kepada guru diharapkan dapat memberikan penerapan pendidikan politik yang baik dan sesuai dengan siswa karena peran dari guru akan sangat berpengaruh terhadap pendidikan politik yang di terima oleh siswa.

3. Pendidikan politik sangat membantu siswa untuk mengenal politik yang berlaku didaerahnya, maka karena itu diharapkan kepada dinas pendidikan agar memberikan pelatihan yang bisa membekali seluruh guru sebagai pendidik untuk menyampaikan pendidikan politik yang baik dan benar.

\section{DAFTAR PUSTAKA}

Arie Putra. 2015. Pentingnya Pendidikan Politik Dan Sosialisasi Pemilu Bagi Masyarakat Terhadap Kualitas HasilPemilu.

Arikunto, Suharsimi. 2016. Prosedur Penelitian Suatu Pendekatan Praktik: EdisiRevisi VI. Jakarta : Rineka Cipta.

Budiardjo, Miriam. 2014. Dasar-Dasar Ilmu Politik. Jakarta: Gramedia Pustaka Utama

Budianto, 2015. Kewarganegaraan. Jakarta:Gelira Aksara Pratama

Djamarah, Bahri Syaiful. 2015. Guru dan anak didik. Jakarta: Rineka cipta Mosoed, mohtar. 2016. Politik, Birokrasi Dan pembangunan. Jakarta: Pustaka Belajar

Nimmo, Dan. 2016. Komunikasi politik. Bandung: Remaja Rodaskarya.

Nazir, Muhammad.2015. Metode Penelitian. Bogor: Gralia Indonesia

Philipus, Ng Dan Nurul Aini. 2014. Pengantar Sosiologi politik. Jakarta: Raja Grafindo Persada.

Rush, Michael Dan Phillip Althoff. 2016. Pengantar Sosiologi politik. Jakarta: Raja Grafindo Persada.

Rush, Michael Dan Phillip Althoff. 2014. Pengantar Sosiologi politik. Jakarta: Raja Grafindo Persada

Tilaar, H.A.R. 2016. Pendidikan kebudayaan Dan Masyarakat Madani Indonesia. Bandung: Remaja Rosdakarya.

Faturachman Alputra. 2014. Budaya, Sosialisasi dan Perilaku Politik Sistem Politik Indonesia, Hamalik, Oemar. 2014. Proses Belajar Mengajar. Jakarta : Bumi Aksara.

Hidayat Syam, 2016. Pengaruh Sosialisasi Keagamaan Tarbiyah Terhadap Loyalitas Partai PKS.

Imron, Ali. 2016. Kebijaksanaan Pendidikan Indonesia. Jakarta: Bumi Aksara.

Sodarsono, Juwono. 2015. Pembangunan Politik dan Perubahan Politik. Jakarta: Graha Media.

Syafie, Kencana Ibnu. 2010. Ilmu Politik. Jakarta: Rineka Cipta

Varma, Sp. 2017. Teori politik modern. Jakarta: Raja Grafindo Persada.

Wijaya, Cece dkk. 2014. Upaya Pembaharuan Dalam Pendidikan dan Pengajaran. Bandung: Remaja Rosdakarya. 
